\title{
ARCHAEOMETRIC STUDY OF ANCIENT MAYA FIGURINES FROM THE COLLECTION OF THE NATIONAL MUSEUM
}

\author{
\#ALEXANDRA KLOUŽKOVÁ*, MÁRIA KAVANOVÁ*, MARTINA KOHOUTKOVÁ**, \\ KATEŘINA KLÁPŠŤOVÁ***, PAVLA DVOŘÁKOVÁ*, ALENA MICHALCOVÁ*** \\ *Department of Glass and Ceramics, University of Chemistry and Technology, Prague, \\ Technická 5. 16628 Prague. Czech Republic \\ **Central Laboratories, University of Chemistry and Technology, Prague, \\ Technická 5, 16628 Prague, Czech Republic \\ ***National Museum - Náprstek Museum, \\ Betlémské náměstí 1, 11000 Prague, Czech Republic \\ \#E-mail: alexandra.klouzkova@vscht.cz
}

Submitted July 20, 2018; accepted August 24, 2018

\begin{abstract}
Keywords: Maya figurines, Maya Blue, Yucatan Peninsula, XRD, XRF, Raman spectroscopy, ceramics, TEM, Náprstek Museum-National Museum, pre-Columbian ceramics

The paper presents the archaeometric study of a unique collection of ancient Maya figurines from the National MuseumNáprstek Museum collection in Prague, Czech Republic. The aim was to characterize ceramic materials of the figurines by three integral techniques (X-ray fuorescence, X-ray diffraction, simultaneous thermal analysis), in order to determine their chemical and mineralogical compositions and to assess possible similarities in the raw materials. The measured data were compared using statistical techniques in order to set up groups of samples according to the diversity in their composition. Further, the surface finishing was evaluated using micro-Raman spectroscopy, infrared spectroscopy, X-ray diffraction and transmission electron microscopy. A great diversity of ceramic bodies was proved. The compositions of figurines show 5 different groups with a varying ratio of main variables $\mathrm{SiO}_{2}, \mathrm{CaO}$ and $\mathrm{Al}_{2} \mathrm{O}_{3}$. The analyses of decorative layers proved that the red pigment, which was used as an aesthetic coating of a jaguar figurine, contains primarily hematite. The other red pigments used to decorate frog and head figurines were of organic origin formed by cochineal dye. The nanostructured wellknown artificial blue pigment Maya Blue was identified on the fragment of a bowl and a man figurine. The results document the material diversity of a unique collection of pre-Columbian ceramics.
\end{abstract}

\section{INTRODUCTION}

Ancient ceramic Maya figurines or figures (the term figurine or figure is used in the context of Maya civilization and implies a group of varied items that include small sculptures of warriors or supernatural beings, musical instruments and jewellery) are currently the subject of many studies. The main goal of these studies is the identification of raw material sources [1-3] and the classification of the figurines according to their compositional differences $[4,5]$. Other studies are focused on the characterization of surface coatings and identification of pigments $[6,7]$. A number of studies deal with the investigation of Maya Blue using different analytical techniques [8-12]. Most papers concern the method of preparation and formation of an artificially synthesized Maya Blue pigment, which is made up of indigo and palygorskite.

The National Museum - Náprstek Museum in Prague possesses the unique collection of Maya figurines from Yucatan Peninsula (Figure 1) which were the objective of this study. It was a gift of Jakub Beer, the Grand Master of the Order of the Knights of the Cross with the Red Star. In 1856, on behalf of the Order, he donated a number of ceramic figurines from Maya preColumbian Mesoamerica of the Maya Classic Period to the Museum of the Kingdom of Bohemia (today's National Museum). The collection was later moved to the building of the National Museum - Náprstek Museum.

In this study, 20 ceramic figurines from the preColumbian classical period of the Maya civilization were studied. These figurines demonstrate a wide iconographic collection of anthropomorphic (e.g. a man with a gesture of adoration, a figure with ceremonial vest covered by Maya Blue, objects in the form of human heads) and zoomorphic (e.g. a jaguar, frog, monkeys) objects and everyday Mayan life objects (e.g. a pyramid etc.). The work was focused on the characterization of the ceramic bodies of the figurines and the determination of their chemical and mineralogical composition using X-ray analyses (XRF and XRD) and thermal analyses (STA) to assess the possibility of similar material composition, use of similar raw materials and processing. A significant part of this work was devoted to the evaluation of surface finishing, especially dyes, which were studied using XRD, micro-Raman spectroscopy ( $\mu-\mathrm{RS})$, infrared spectroscopy (IR) and transmission electron microscopy (TEM). 


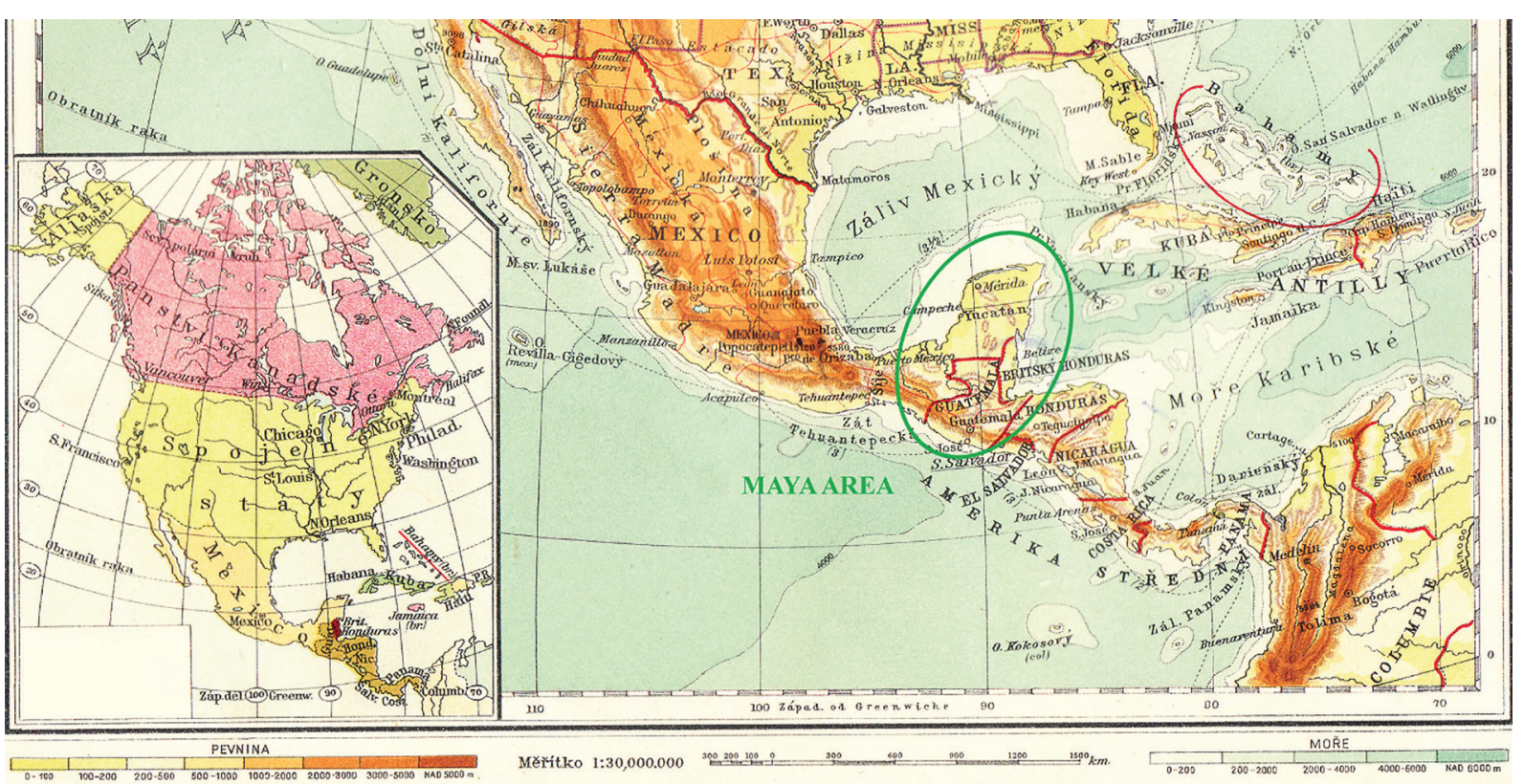

Figure 1. Yucatan Peninsula (green circle) in 1926 [13].

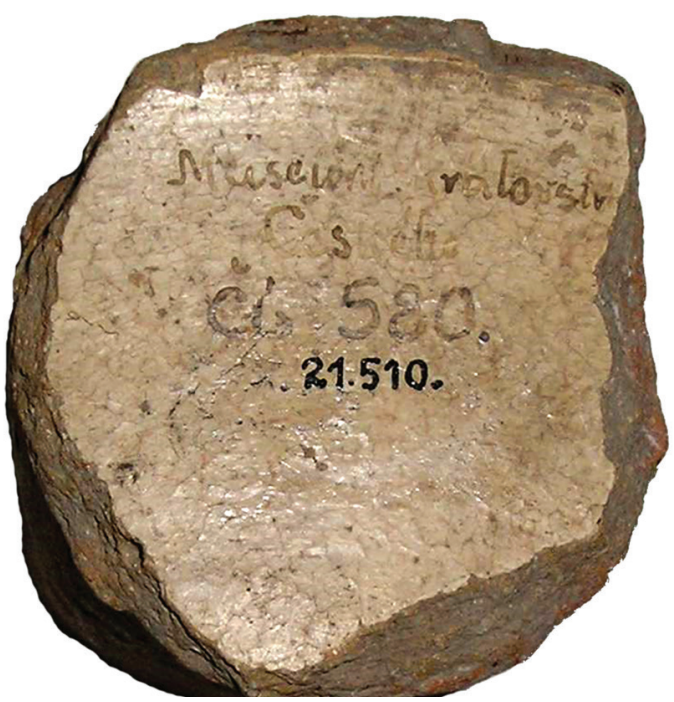

Figure 2. Maya figurine (inv. no. 21510) with a historical inscription.

\section{EXPERIMENTAL}

Ceramic bodies of a human head with a red surface treatment (inv. no. 21493, Figure 3), a frog with a dark brown-black surface (inv. no. 21454, Figure 4), a reliefdecorated foot of a bowl with remains of a dark blue colour (inv. no. 21511, Figure 5), a man in a garment with fringes with remains of blue surface treatment (inv. no. 21507, Figure 6), a jaguar with remains of a red surface treatment (inv. no. 21517, Figure 7), an ocarina A - a man with a pectoral and a lumbar veil with a white décor (inv. no. 21508, Figure 8), an ocarina B - a man with a pectoral and a lumbar veil with a white décor (inv. no. 21516, Figure 9) along with 13 other figurines were studied by XRF and XRD analyses. Five ceramic bodies of selected figurines (inv. no. 21511, 21517, 21503, 56549,21493 ) were also analysed by STA. Samples for the analyses were grounded in an agate mortar into the form of a fine powder and well dried at $105^{\circ} \mathrm{C}$ in a laboratory oven.

Surface decorative layers of four selected figurines (inv. no. 21454, 21507, 21511 and 21517) were studied using XRD, $\mu$-RS, IR and TEM. Very small samples of pigment residues were removed from the figurine surfaces and subjected to the analyses.

The chemical composition of the ceramic bodies was measured by X-ray fluorescence analysis (XRF), using an ARL 9400 XP sequential WD-XRF spectrometer equipped with a $\mathrm{Rh}$ anode X-ray tube type 4GN fitted with a $50 \mu \mathrm{m}$ Be window. The obtained raw data were evaluated using the software WinXRF. Standardless analyses were completed with the software Uniquant 4.

The mineralogical composition of the ceramic bodies and pigments was determined by X-ray diffraction analysis (XRD). X-ray data were collected using PANanalytical X'Pert PRO powder diffractometer with parafocusing Bragg-Bretano geometry using $\mathrm{CuK} \alpha$ radiation at ambient temperature over the angular range of $5-70^{\circ}(2 \theta)$. Data evaluation was performed using the PANalytical High Score Plus 4.0 software package.

The mineralogical composition of the selected ceramic bodies was also studied by simultaneous thermal analysis (STA) in TG-DTA mode using LINSEIS STA PT $1600 / 1750^{\circ} \mathrm{C}$ HiRes. The samples were measured in the form of fine powders in helium flow at the rate of $10^{\circ} \mathrm{C} \cdot \mathrm{min}^{-1}$ from ambient temperature to $1000^{\circ} \mathrm{C}$. Measurements of $50 \pm 0.05 \mathrm{mg}$ samples were performed in platinum crucibles. $\mathrm{H}_{2} \mathrm{O}$ and $\mathrm{CO}_{2}$ releases were detected by mass spectrometer ThermoStar ${ }^{\mathrm{TM}}$ GD320 in the range of $300 \mathrm{AMU}$. 


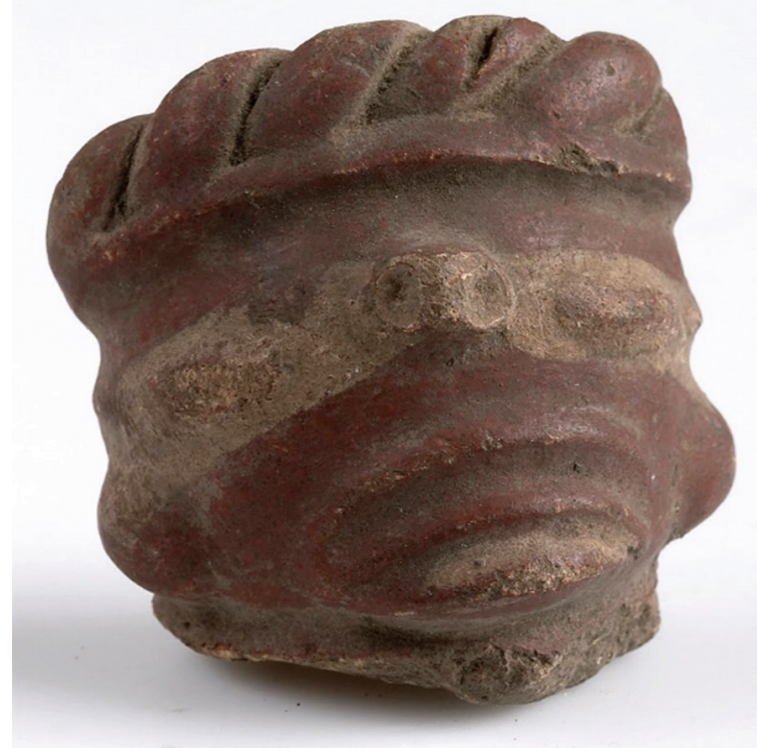

Figure 3. A human head (inv. no. 21493).

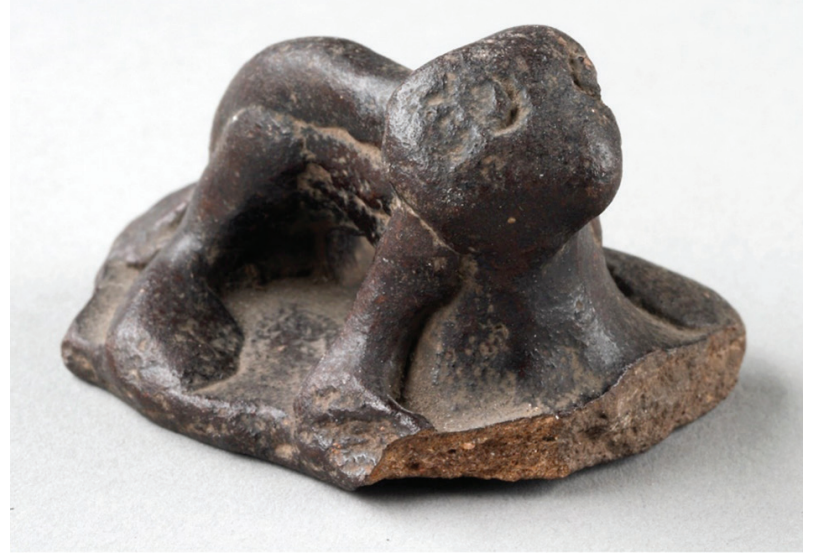

Figure 4. A frog figurine (inv. no. 21454).

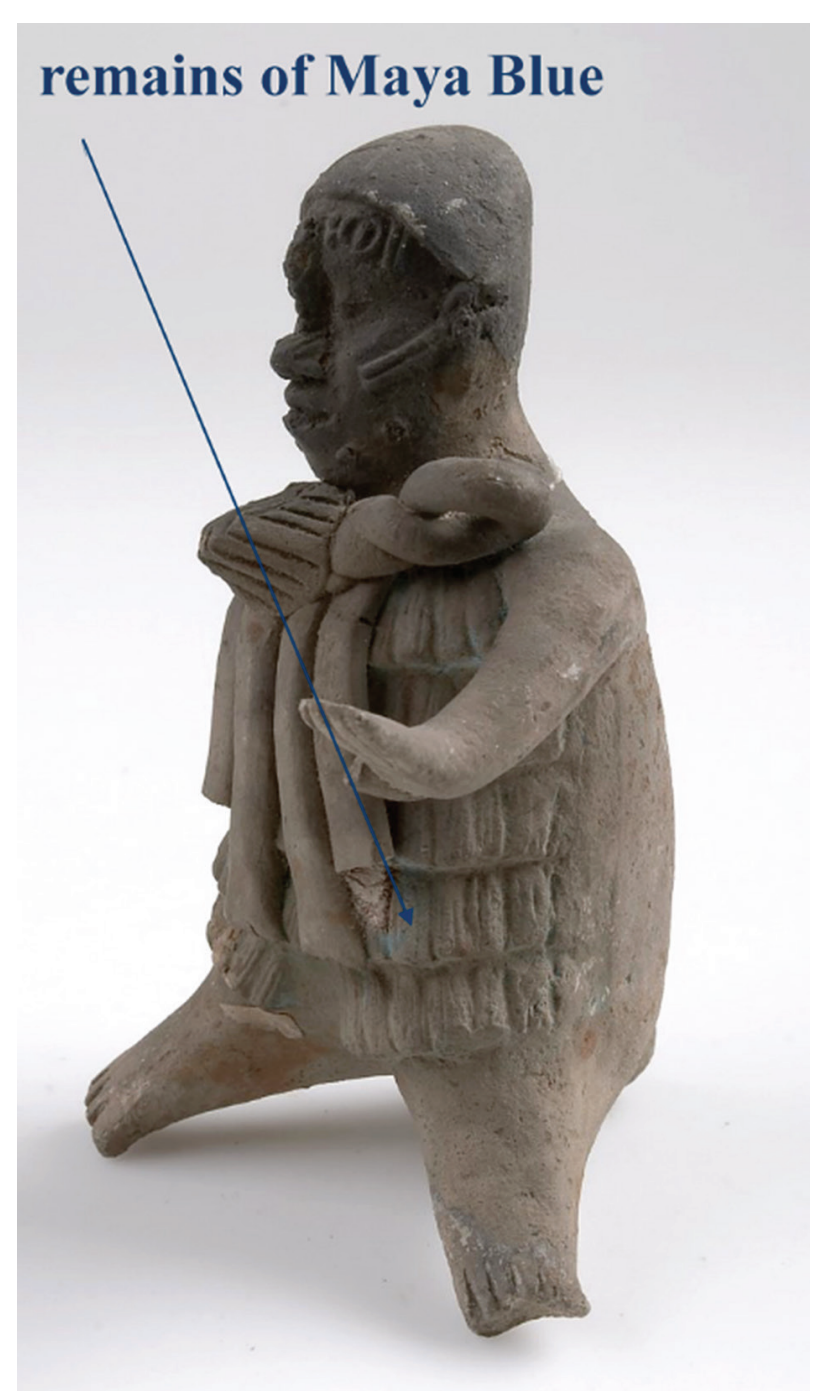

Figure 6. A man figurine (inv. no. 21507).

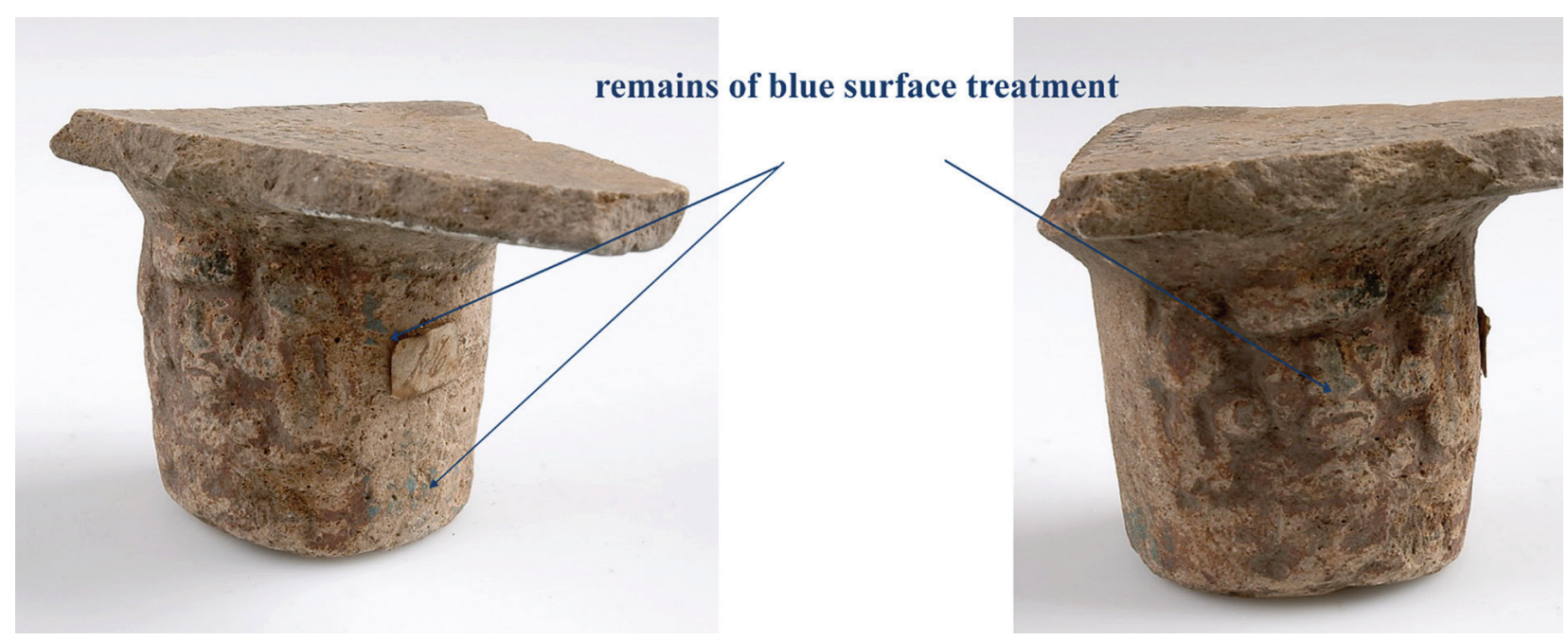

Figure 5. A feet of a bowl (inv. no. 21511). 


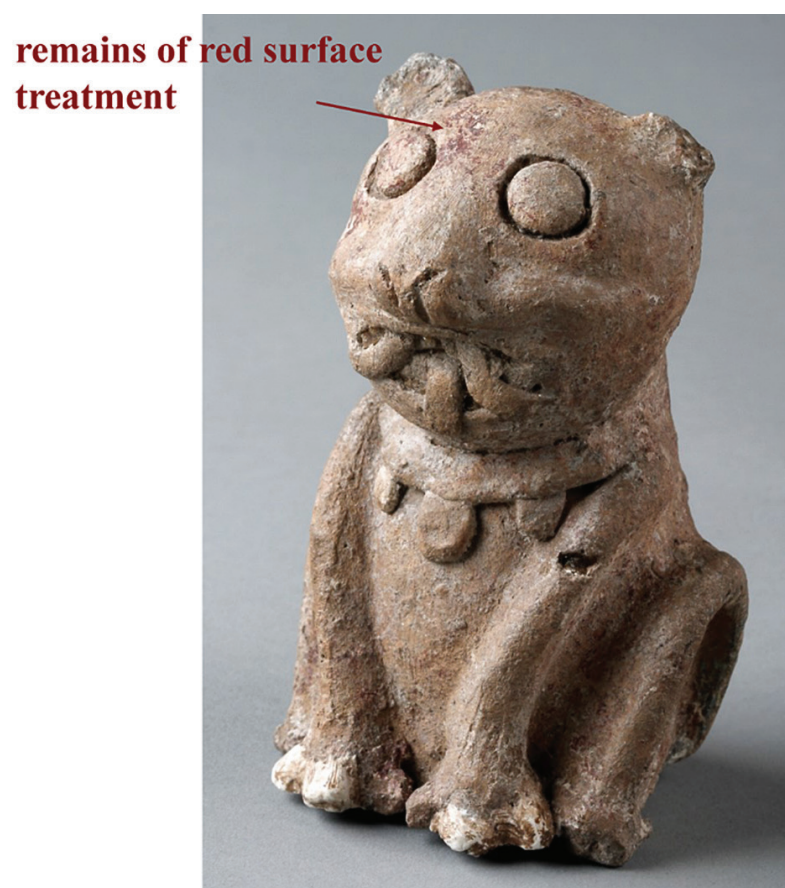

Figure 7. A jaguar figurine (inv. no. 21517).

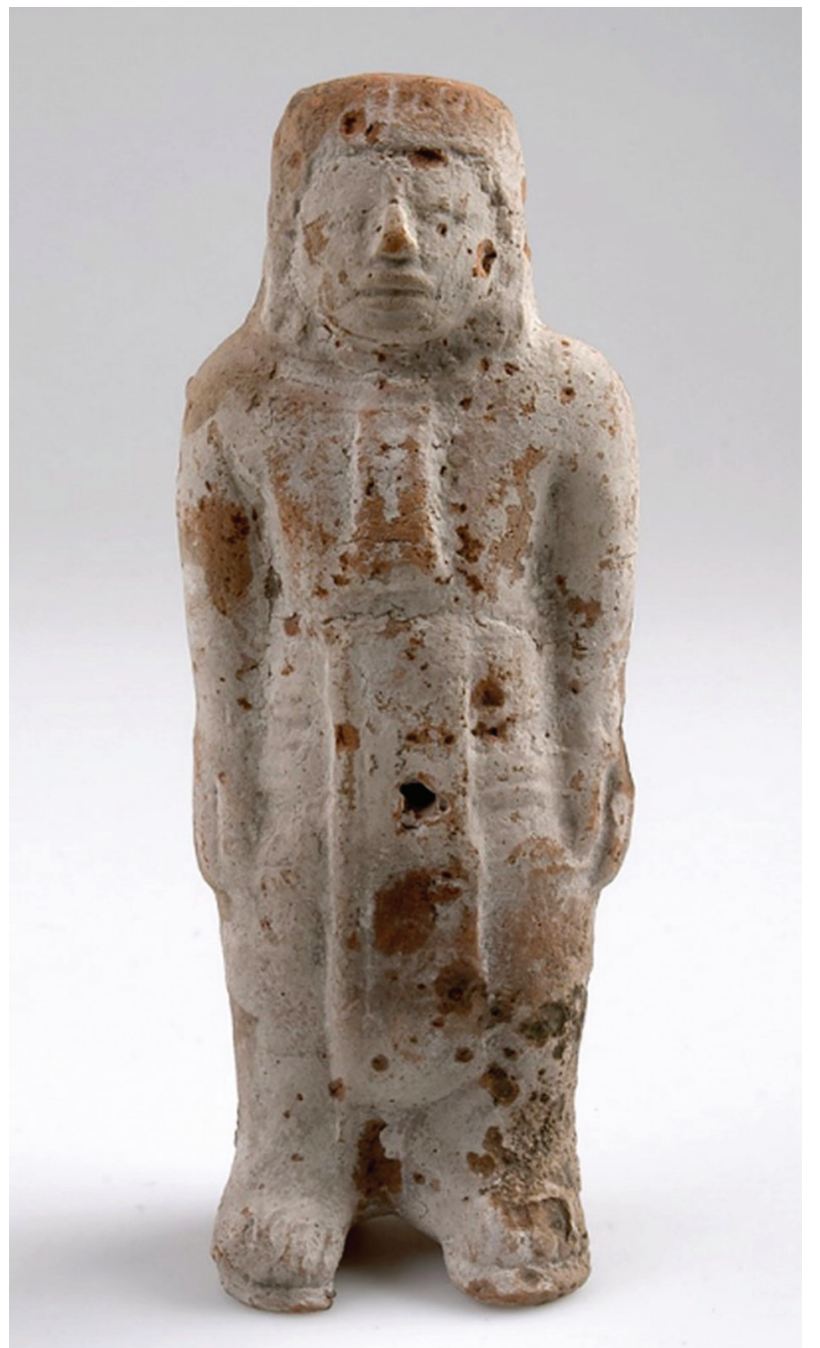

Figure 8. An ocarina A (inv. no. 21508).

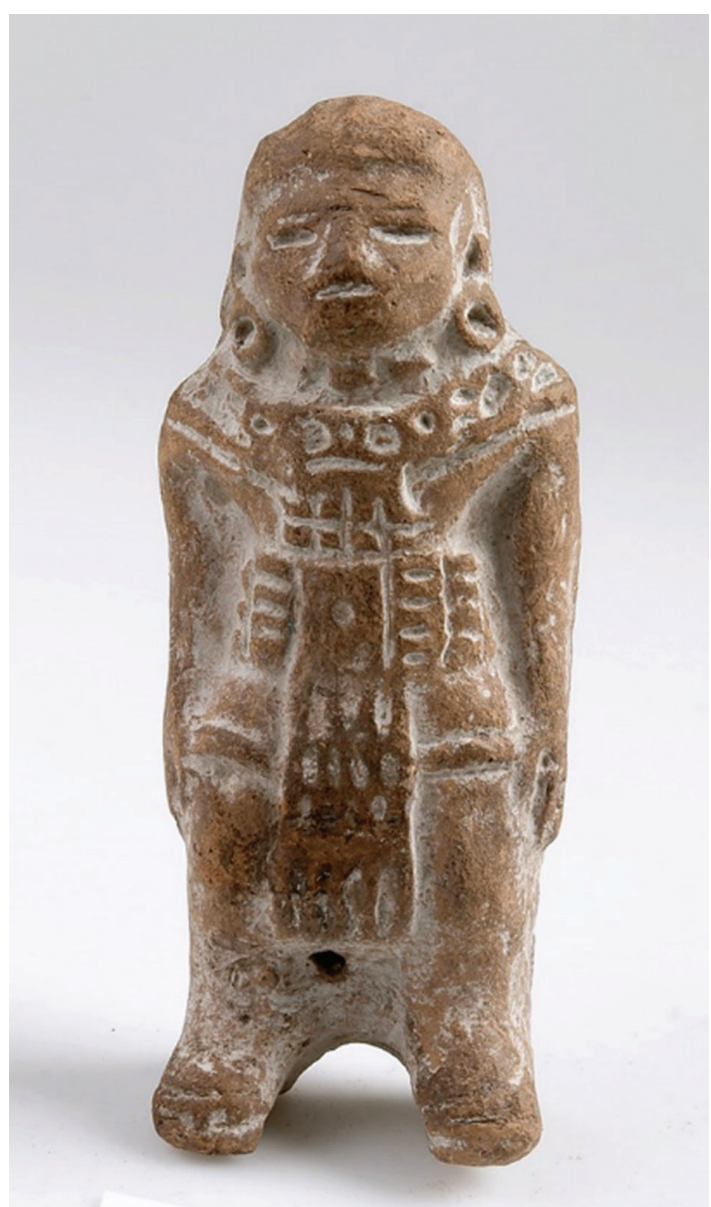

Figure 9. An ocarina B (inv. no. 21516).

Micro-Raman spectroscopy $(\mu-\mathrm{RS})$ was performed using Thermo Scientific Nicolet DXR Jobin Yvon Labram HR equipped with a confocal microscope. The samples were excited by a He-Ne laser, operating at light wavelengths of $\lambda=532 \mathrm{~nm}$ and $\lambda=785 \mathrm{~nm}$ with maximum nominal powers of $50 \mathrm{~mW}$ and $40 \mathrm{~mW}$, respectively. The signal was collected by a liquid nitrogen cooled charge-coupled detector (CCD) equipped with a grating of 1800 and 600 grooves/ $\mathrm{mm}$, allowing a final spectral resolution of $3 \mathrm{~cm}^{-1}$. The laser light was focused on a sample surface by means of optical objectives $(10 \times, 20 \times, 50 \times$ and $100 \times$ zoom). Spectra of dried samples of surface treatment layers were also collected by FT-infrared spectroscopy (FTIR), using a Thermo Scientific Nicolet 6700 spectrometer equipped with an MCT detector. Single beam spectra were obtained against air as a background in the range of $4000-600 \mathrm{~cm}^{-1}$ at a resolution of $4 \mathrm{~cm}^{-1}$ and a total of 128 co-added scans. The Raman and IR spectra obtained were subsequently evaluated using the software Omnic 7.3.

The nanostructural features of the surface coatings, especially the blue pigment, were analysed using transmission electron microscopy (EFTEM Jeol 2200 FS). The TEM is equipped with an energy filter and can work at accelerating voltages up to $200 \mathrm{kV}$. 


\section{RESULTS AND DISCUSSION}

Chemical composition

Chemical compositions of the ceramic bodies determined by XRF analysis are presented in Table 1. XRF results obtained for the 20 analysed ceramic bodies were analysed using multivariable calculations of principal components and are presented in the form of the principal component biplot (Figure 10). The multivariate analysis showed distribution of the objects into four groups based on the different content of the three main components $\left(\mathrm{SiO}_{2}, \mathrm{Al}_{2} \mathrm{O}_{3}\right.$ and $\left.\mathrm{CaO}\right)$. One sample, the figurine of a fish inv. no. 21503 , having a very high content of $\mathrm{CaO}$ and low contents of the other components remained separated from the four groups A, B, C, D. The biplot shows only abbreviated sample names for better clarity without the first two digits 21 .

\section{Mineralogical composition}

Mineralogical compositions obtained by evaluating the XRD patterns of ceramic bodies of the analysed collection are shown in Table 2. The XRD results are in a good agreement with the XRF results. The figurine of a fish contained only calcite and traces of quartz. Figurines of group A contained calcite as the main crystalline phase accompanied by small amount of quartz and mica. XRD patterns of the figurines of group B showed high content of an amorphous phase which could be attributed to non-crystalline metaclays. The mineralogical composition of figurines of group $\mathrm{C}$ was very similar to that of figurines of the group A, except for identification of traces of the clay mineral kaolinite. Figurines of the group D contained quartz as the main crystalline phase; further small amounts of mica, feldspars, calcite and gypsum were identified. The exception in the group is the figurine of a head inv. no. 21493 which showed a high content of an amorphous phase and only traces of quartz.
Figures 11-15 show diffraction patterns of ceramic bodies of five selected figurines which are representatives of the distribution groups. The figurine of a jaguar inv. no. 21517, the representative of group A, contained calcite as the main crystalline phase, accompanied by a very small amount of quartz and mica. Figure 11 shows the XRD pattern of the ceramic body of the man figurine inv. no. 21507 (group B) with quartz as the main crystalline phase and small amounts of mica, feldspars and gypsum. Group $\mathrm{C}$ is represented by the figure of the bowl inv. no. 21511, having calcite as the main crystalline phase, accompanied by very small amounts of quartz, mica and kaolinite. Figures 14 and 15 show XRD patterns of two figurines from group D - the ocarina B inv. no. 21516 and the head inv. no. 21493. The figurine of an ocarina contained quartz as the main crystalline phase, accompanied by calcite, mica and traces of plagioclase. On the other hand, the figurine of the head contained only traces of quartz, and its main crystalline phase is plagioclase. An increased background of the XRD pattern shows the presence of a high amount of an amorphous phase.

The mineralogical composition of selected representative figurines of the groups A to D (inv. no. 21503, $21517,56549,21511$ and 21493) was also evaluated by thermal analyses. Figure 16 shows the comparison of measured DTA-TG curves complemented by curves of released gases $\mathrm{H}_{2} \mathrm{O}$ (blue curves) and $\mathrm{CO}_{2}$ (green curves). The results of thermal analyses correspond well with the results of XRD. The left hand side of Figure 16 shows DTA-TG and gas release curves of the samples inv. no. 21511 and 21517 (groups A and C), while inv. no. 21503 illustrates mainly the decomposition of carbonates which were identified as the main crystalline phase by XRD. It is highly probable that the figurine of the fish inv. no. 21503 was not prepared from a ceramic raw mixture but from a piece of a calcitic rock, as the results of XRD and STA proved the presence of only calcite with traces of quartz. In samples inv. no. 21511 and 21517 the
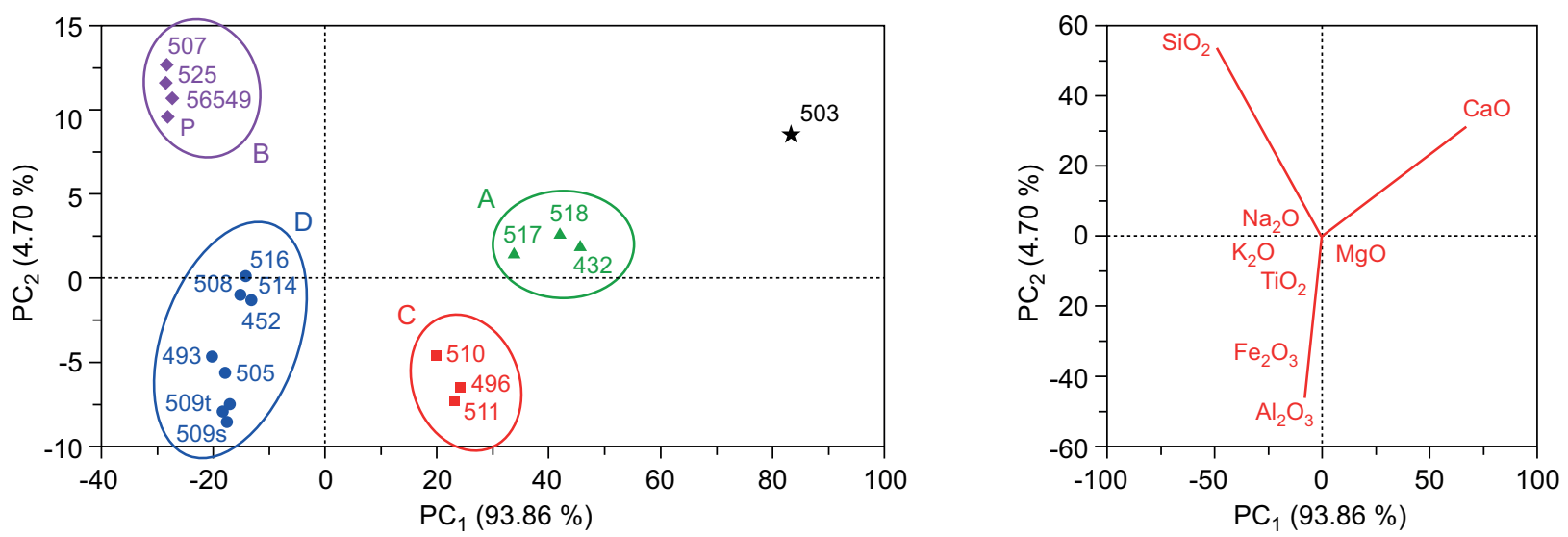

Figure 10. The principal component biplot of XRF results of the ceramic bodies (left hand side) and the main active variables biplot (right hand side). 
carbonates were accompanied by small amounts of clay minerals. Curves of these two samples show dehydration in the range $50-280^{\circ} \mathrm{C}$. The curves of the sample inv. no. 21517 indicates also dehydroxylation $\left(300-550^{\circ} \mathrm{C}\right)$ of metaclays. On the other hand, no evidence of decomposition of carbonates was observed in the curves of samples inv. no. 56549 and 21493 (groups B and D); a slight increase of the $\mathrm{CO}_{2}$ curve is associated with the burning of organic residues from the ceramic body during the thermal load. DTA-TG curves of these two figurines illustrate the dehydratation and dehydroxylation of metaclays over the range $50-510^{\circ} \mathrm{C}$.

\section{Surface treatment}

Surface decorative layers of four selected figurines (inv. no. 21454, 21507, 21511 and 21517) were studied using XRD, $\mu$-RS, IR and TEM.

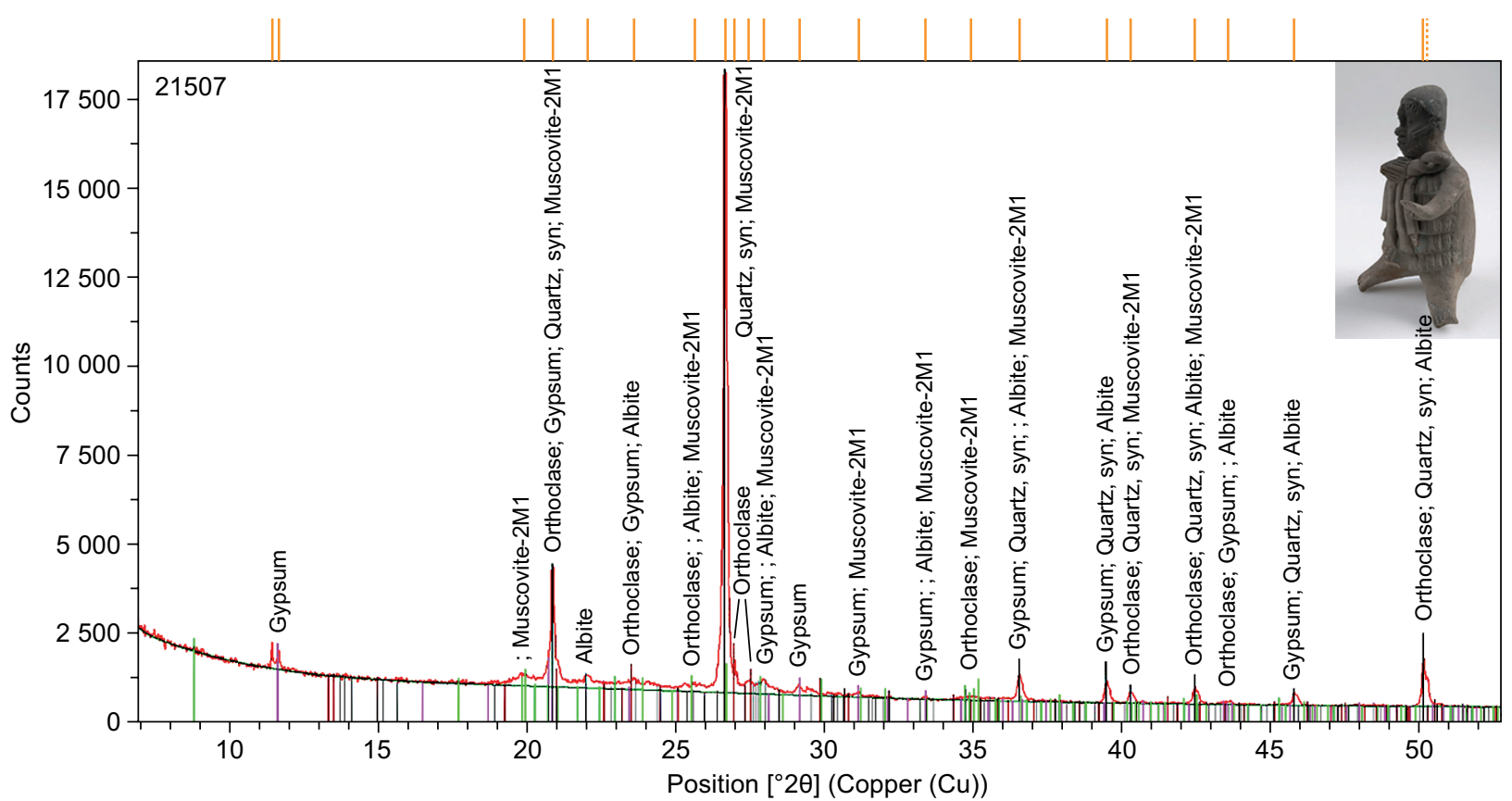

Figure 11. XRD pattern of the ceramic body of the man figurine inv. no. 21507.

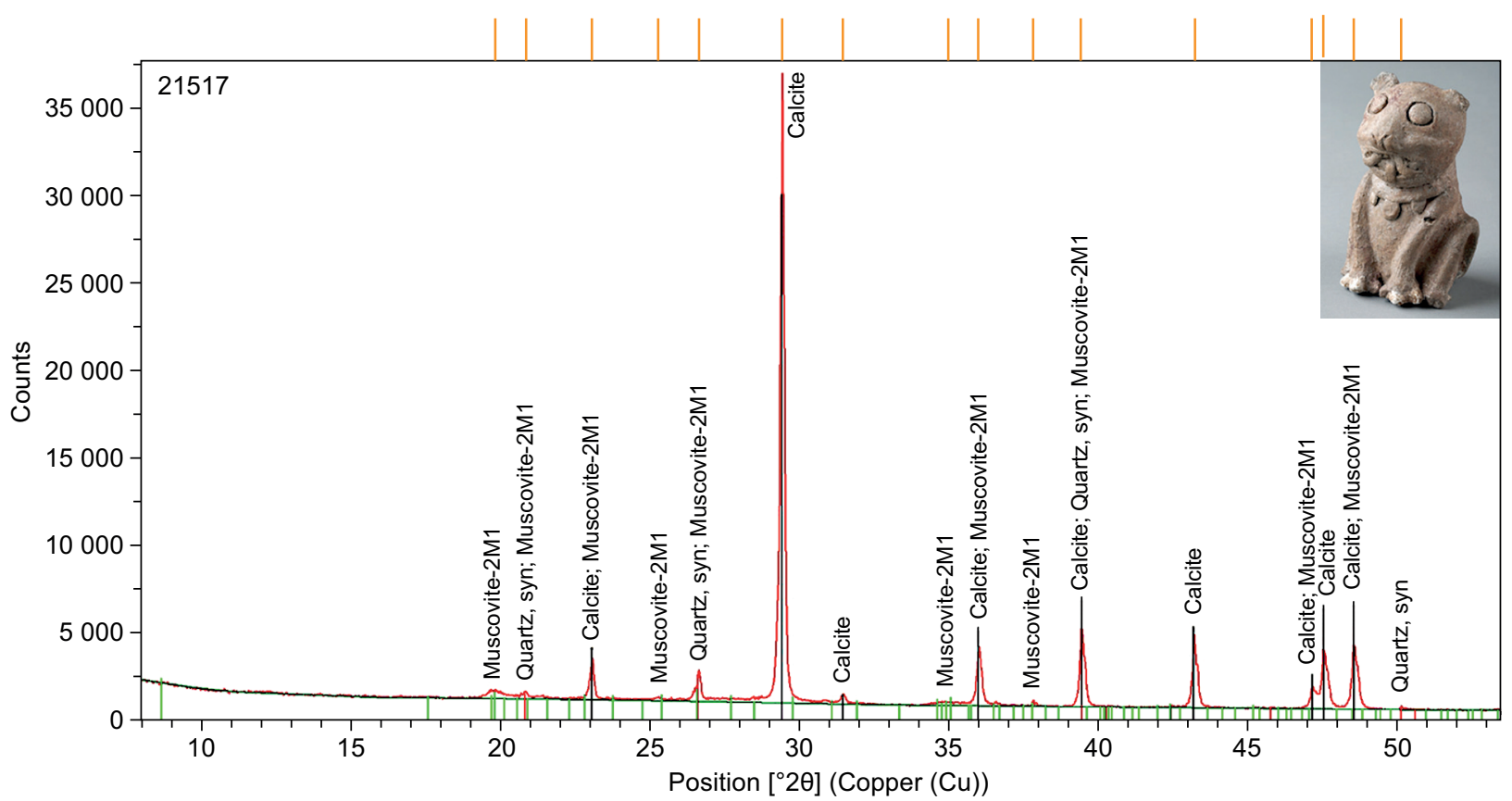

Figure 12. XRD pattern of the ceramic body of the jaguar inv. no. 21517. 


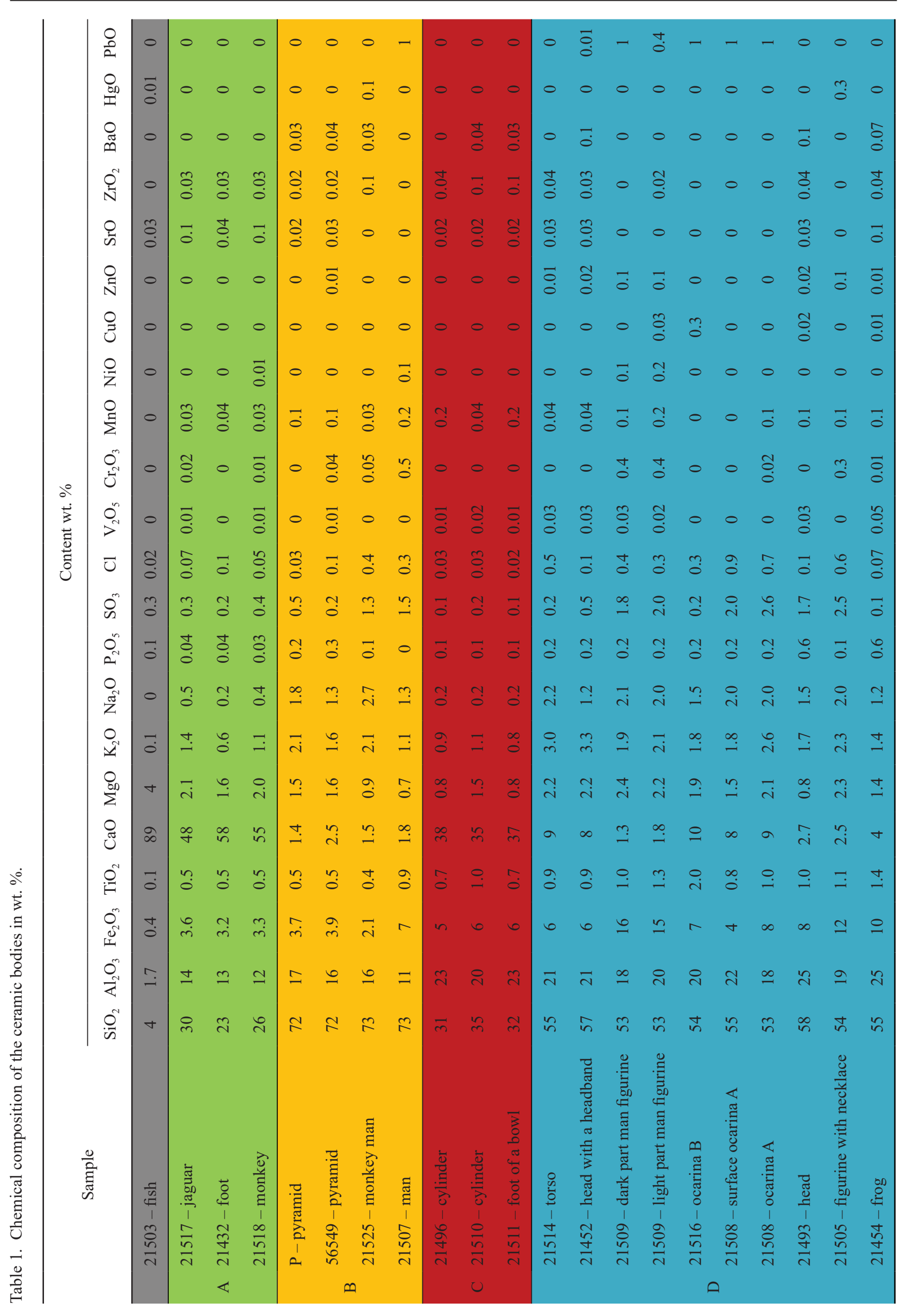




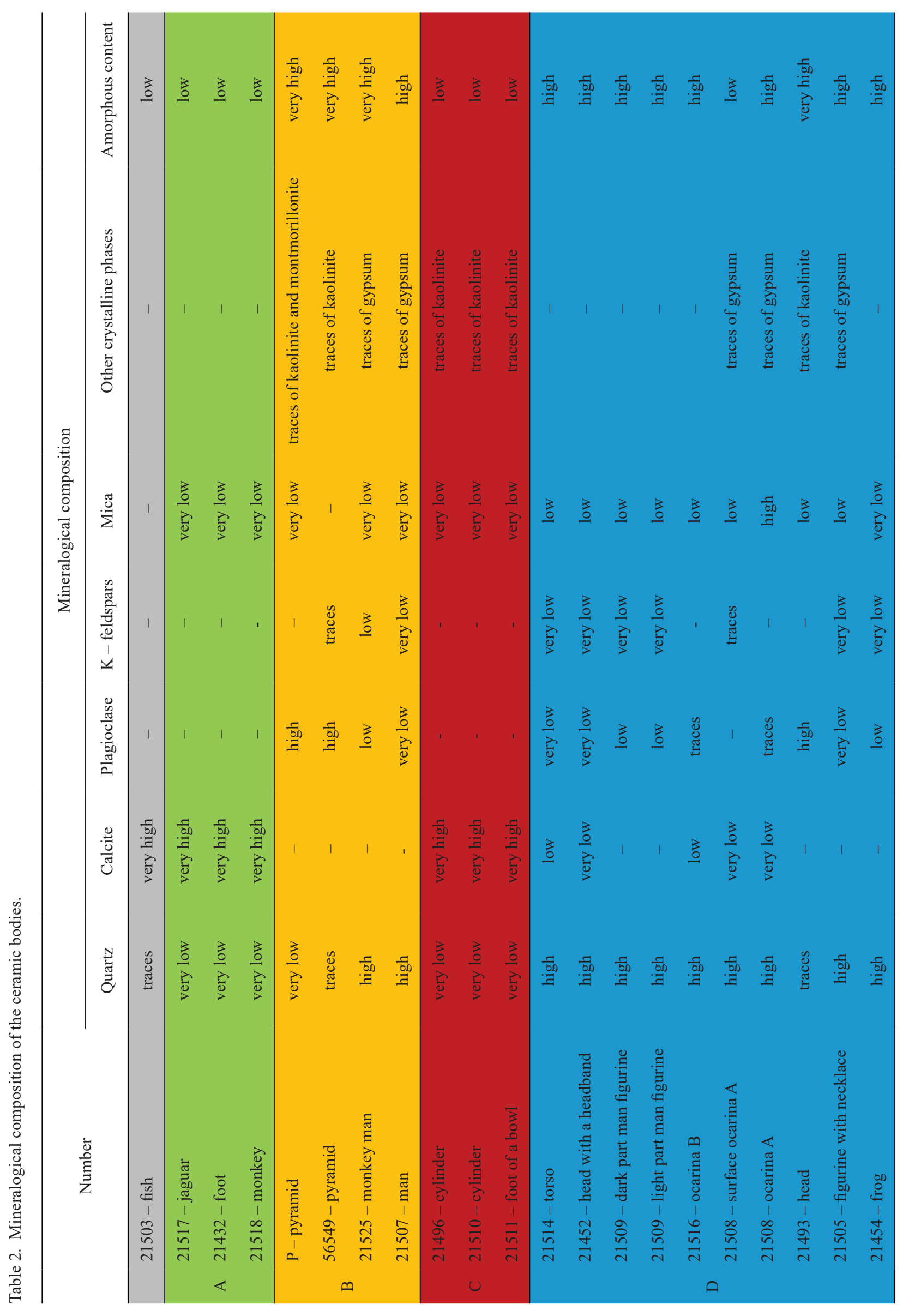


The blue layer taken from the man figurine inv. no. 21507 was identified as palygorskite by XRD (Figure 17), $\mu$-RS (Figure 22) and TEM (Figure 23) analyses. XRD of this sample also proved the presence of gypsum which was probably used to raise the blue colour. The presence of palygorskite was identified by XRD also in the sample of the bowl figurine inv. no. 21511. Diffraction lines of the identified palygorskite matches well reference pattern 04-013-5979 of palygorskite from the locality of Ticul (the locality near Uxmal) in Mexico, where an ancient fabrication of a Maya Blue pigment was documented by archaeologists. XRD patterns of the samples inv. no. 21457, 21517 showed no crystalline phase except quartz and calcite which probably originate from the ceramic bodies of the figurines.

The presence of palygorskite and indigo that are the main components of Maya Blue pigment was confirmed by Raman spectroscopy. The intensity of blue colour

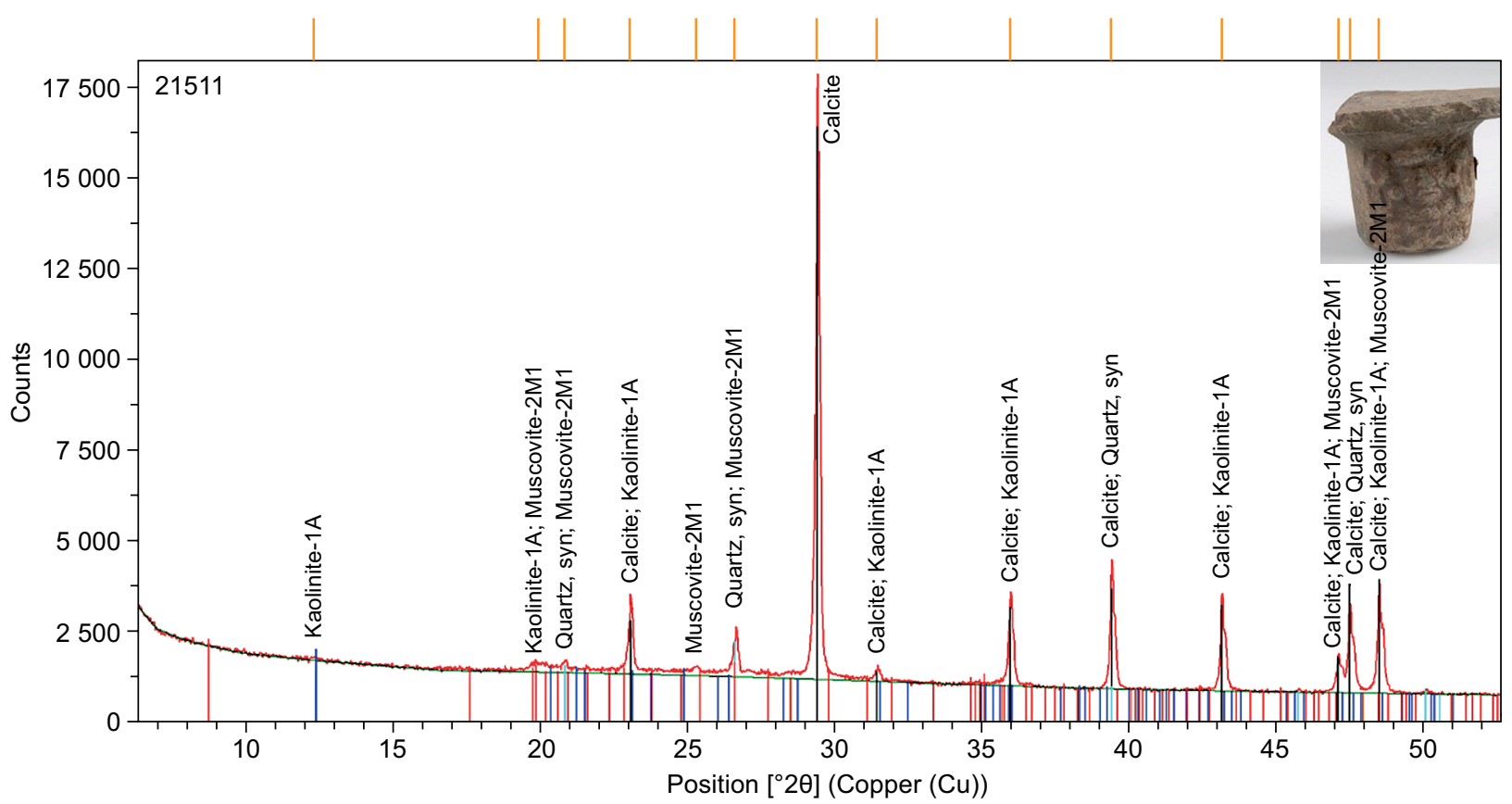

Figure 13. XRD pattern of the ceramic body of the foot of the bowl inv. no. 21511.

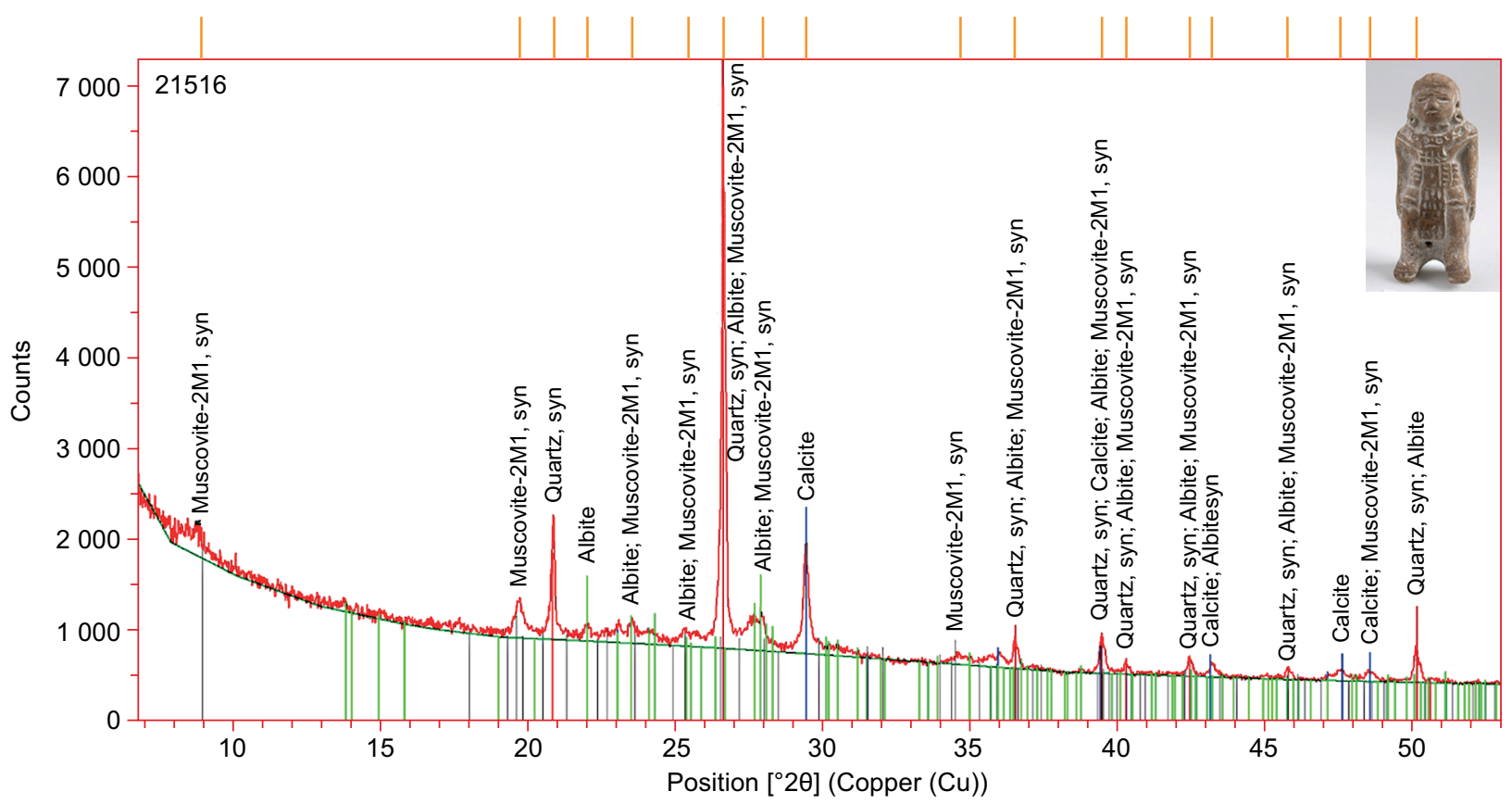

Figure 14. XRD pattern of the ceramic body of the ocarina B inv. no. 21516. 
was controlled by admixture of gypsum. An organic cochineal dye was identified in the surface treatments of the frog (inv. no. 21454) and the human head (inv. no. 21493) figurines. In case of the human head samples it was in combination with gypsum. A protein binder in the form of glue was probably used as a binder.

The infrared spectra of the human head and the frog are shown in Figures 19 and 20, together with the spectrum of the dye cochineal (the bottom spectrum). Vibration bands at wavenumbers 1568 resp. 1562, 1447, $1373 \mathrm{~cm}^{-1}$ correspond to the main colouring component of cochineal carminic acid (carmine). The carmine vibration bands are usually overlapped by other bands due to the preparation of insect bodies. Furthermore, the bands of cochineal of the human head are complemented by typical bands of gypsum $\left(1138,1161,3413,3570 \mathrm{~cm}^{-1}\right)$.
The Raman spectrum of the jaguar was compared with a spectrum of hematite pigment which is presented in Figure 21. All the most significant bands $(225,245$, $298,411,612,1321 \mathrm{~cm}^{-1}$ ) in the Raman spectrum of hematite were identified in the surface coating of the jaguar figurine without any additional bands.

The Raman spectrum of Maya Blue pigment from the surface of the man figurine was measured using 532 and $785 \mathrm{~nm}$ excitations. Figure 22 shows the comparison of the measured spectrum with synthetic Maya Blue pigment which was measured using the same measuring technique under the same conditions. The Raman spectrum of pigment presents the coalescence of indigo bands at 1576 and $1593 \mathrm{~cm}^{-1}$. In Maya Blue were observed some indigo bands $(599,672,1147,1361$ $\left.1576 \mathrm{~cm}^{-1}\right)$ and also some shifted bands or intensity changes $\left(1253,1378,1491,1593\right.$ and $\left.1680 \mathrm{~cm}^{-1}\right)$.

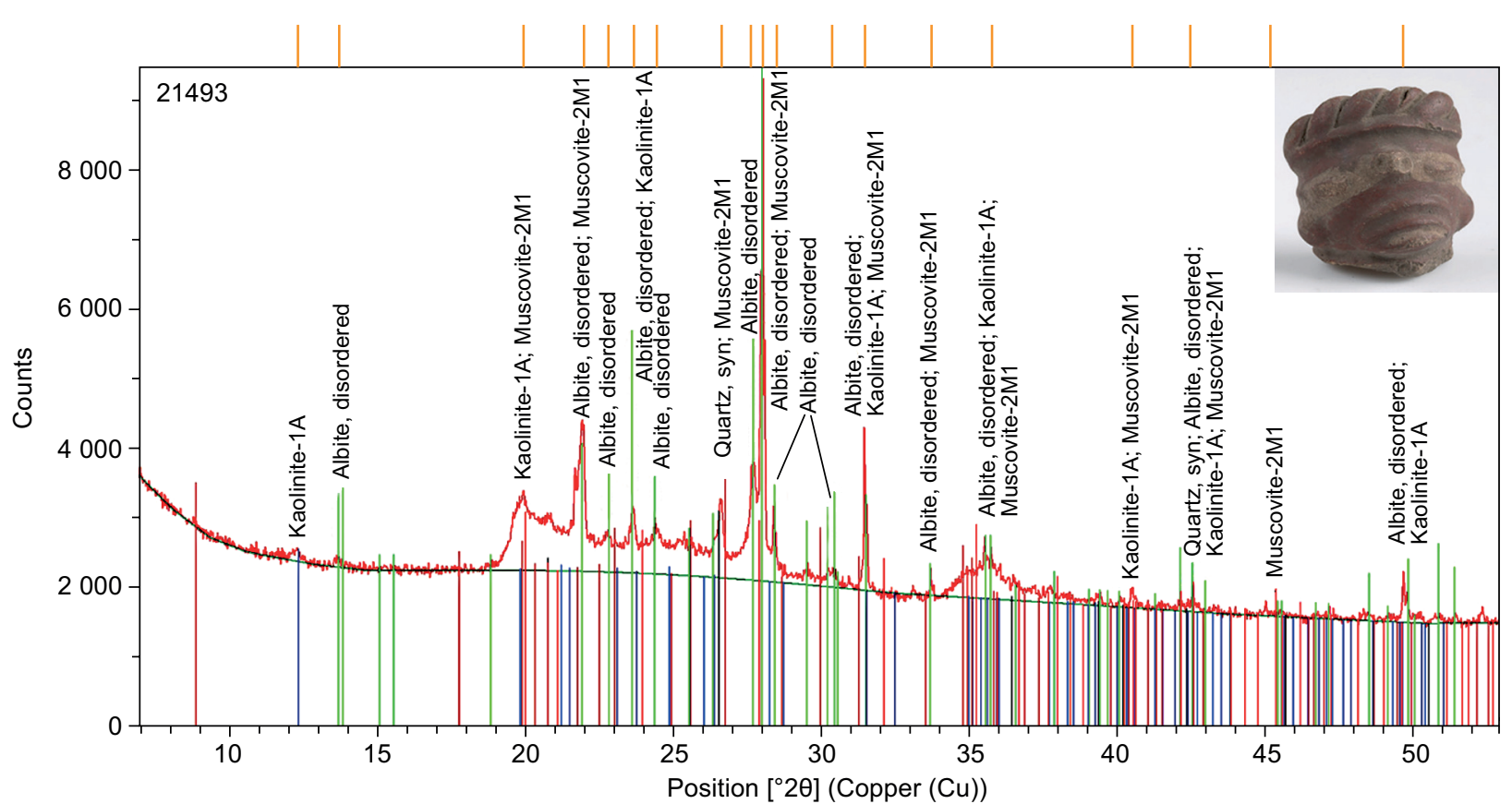

Figure 15. XRD pattern of the ceramic body of the head inv. no. 21493.

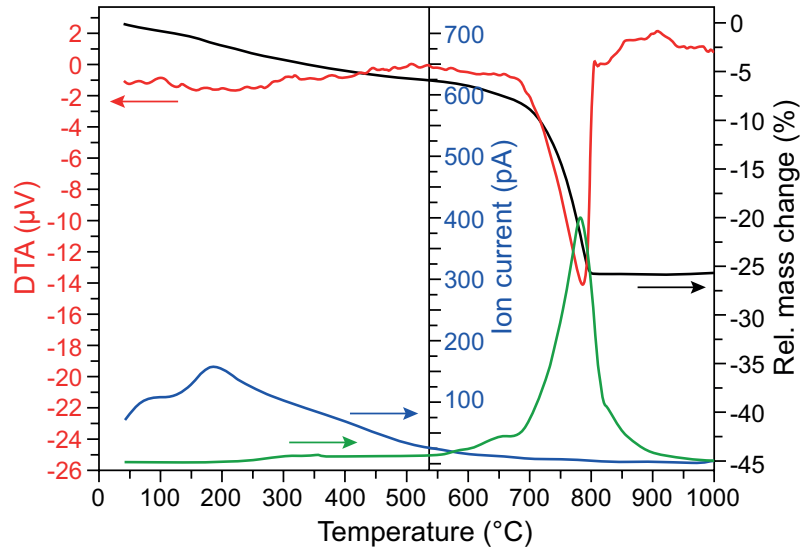

a) inv. no. 21511

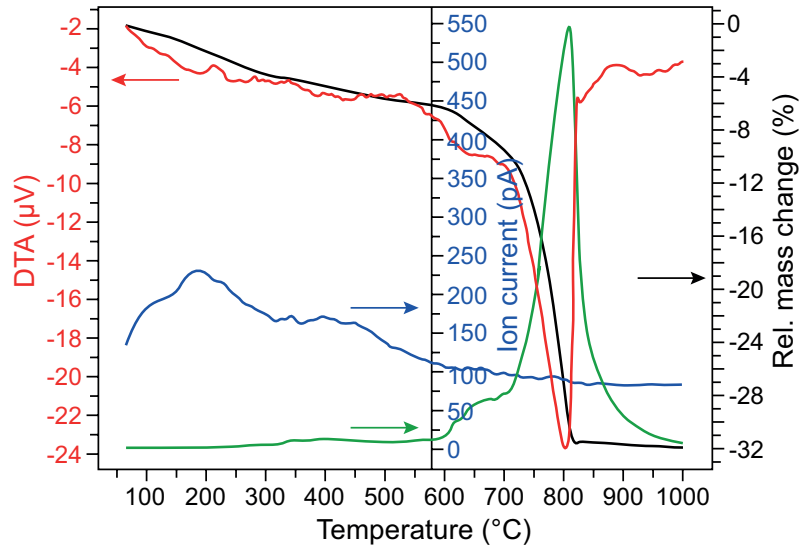

b) inv. no. 21517

Figure 16. STA curves with $\mathrm{H}_{2} \mathrm{O}$ and $\mathrm{CO}_{2}$ release curves of selected ceramic bodies. (Continue on next page) 


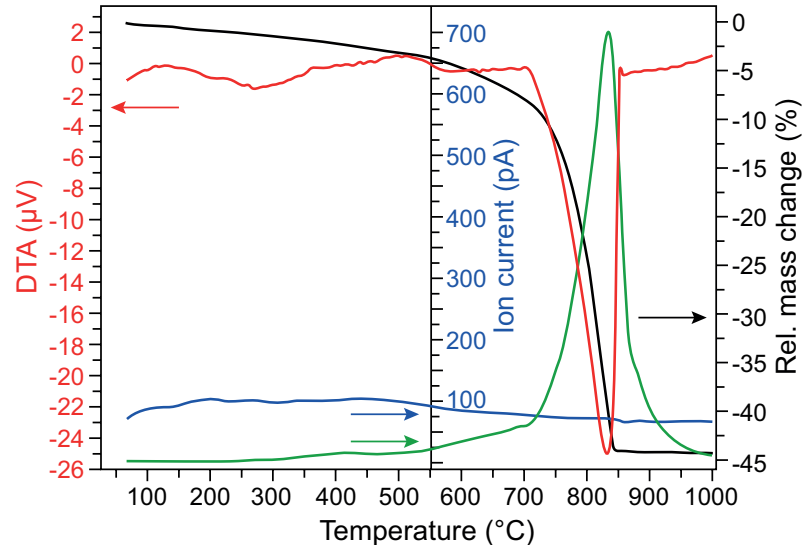

c) inv. no. 21503

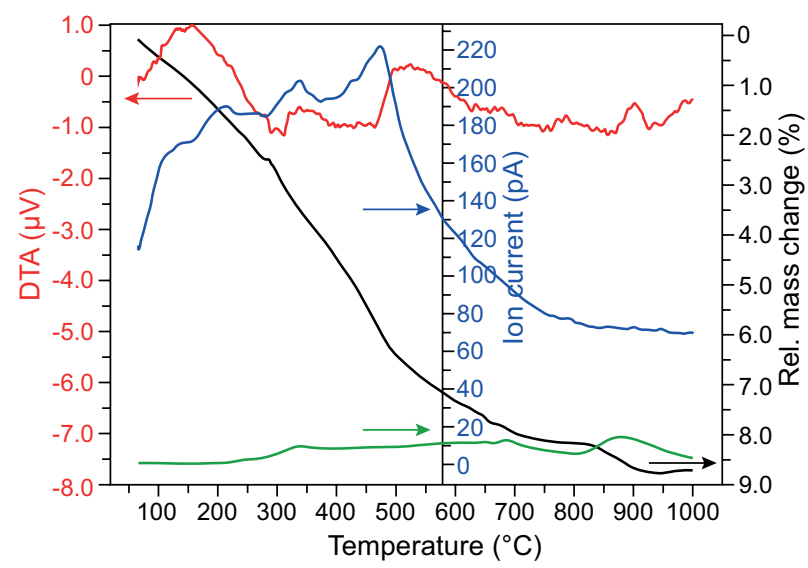

e) inv. no. 21493

Figure 16. STA curves with $\mathrm{H}_{2} \mathrm{O}$ and $\mathrm{CO}_{2}$ release curves of selected ceramic bodies.

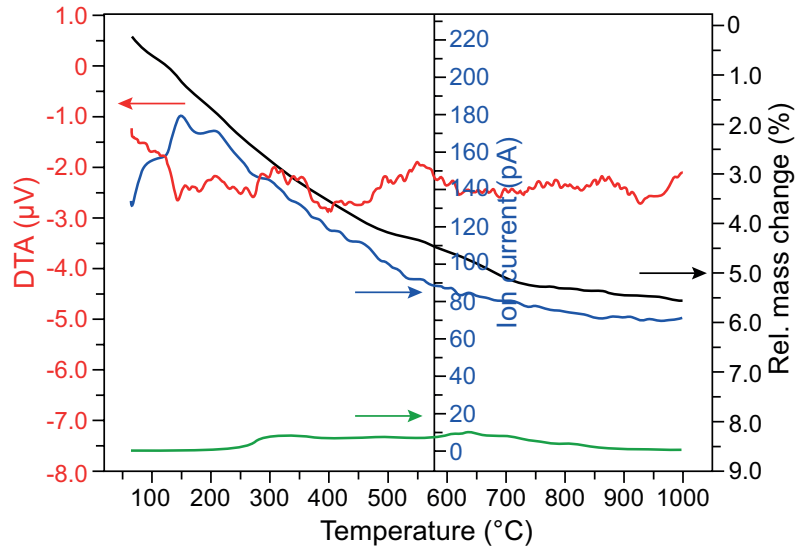

d) inv. no. 56549

Microscopic evaluation

The transmission electron microscopy micrographs of the blue pigment from the man figurine inv. no. 21507 show very well developed and tightly packed rod-like crystals of palygorskite (Figure 23, right hand side) with the successful binding of a blue indigo dye.

TEM observation detected fibrous crystals of palygorskite clay. These fibres had creased surfaces which is associated with the degradation of structure due to water transfer from the structure. The indigo molecules are implemented on the external surface (Figure 23, left hand side). Palygorskite nanoparticles of varying size from 5 to $35 \mathrm{~nm}$ were tightly stacked and formed clusters which were covered with indigo particles.

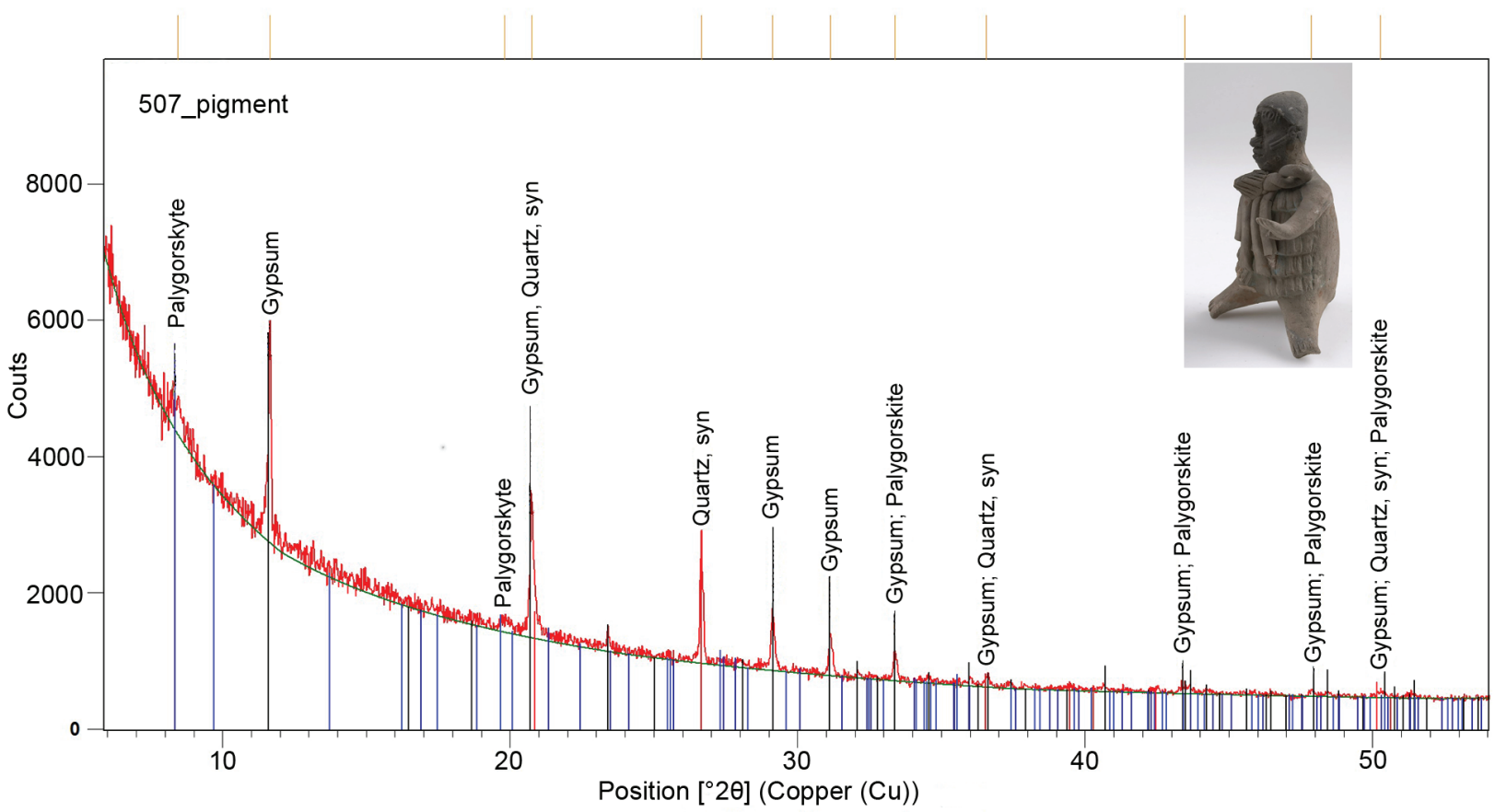

Figure 17. XRD pattern of a blue pigment of the man figurine inv. no. 21507. 


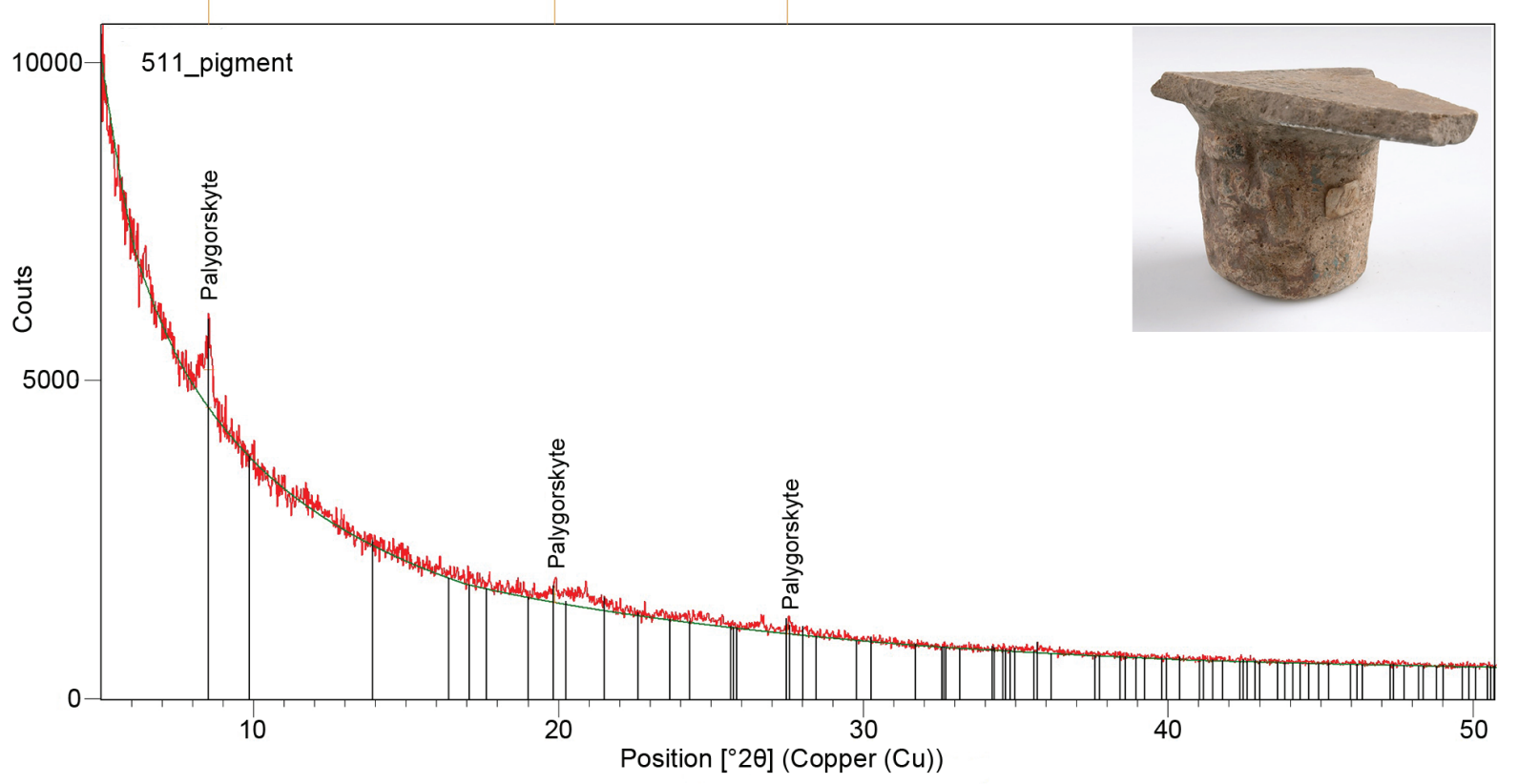

Figure 18. XRD pattern of a light blue pigment of the foot of the bowl inv. no. 21511.

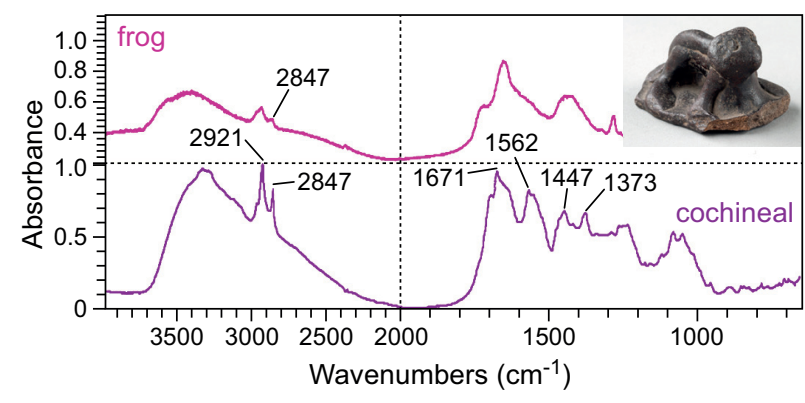

Figure 19. Infrared spectra of red grains in the surface treatment of the frog figurine (inv. no. 21454).

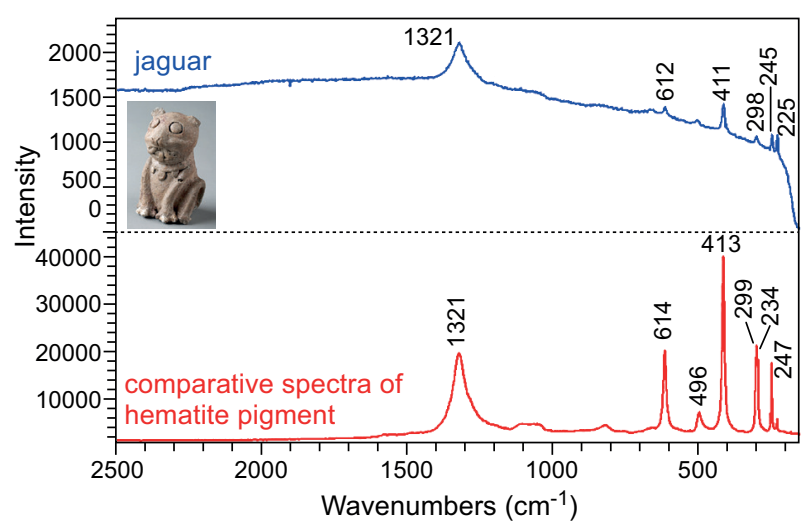

Figure 21. Raman spectra of red grains in the surface treatment of the jaguar figurine (inv. no. 21517).

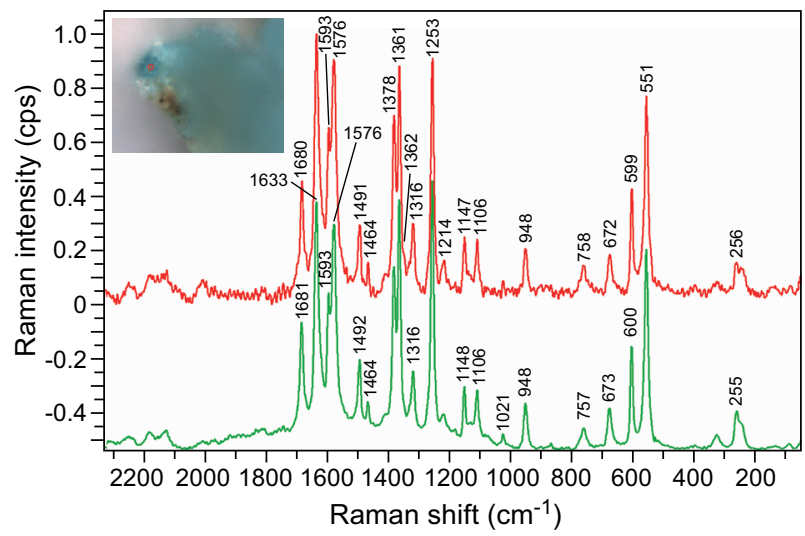

Figure 22. Raman spectra of blue grains in the surface treatment of the man figurine (inv. no. 21507).

of the human head figurine (inv. no. 21493). 


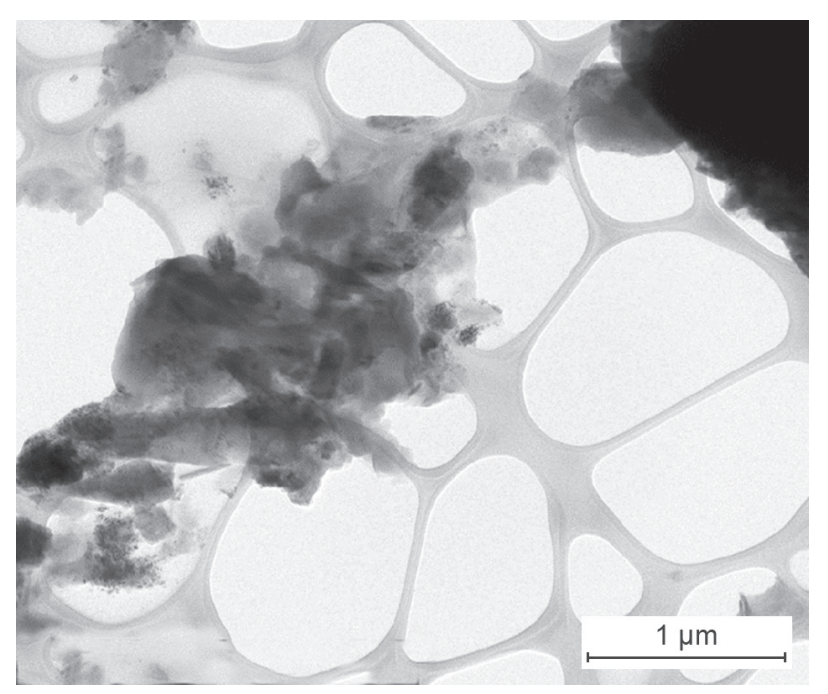

a)

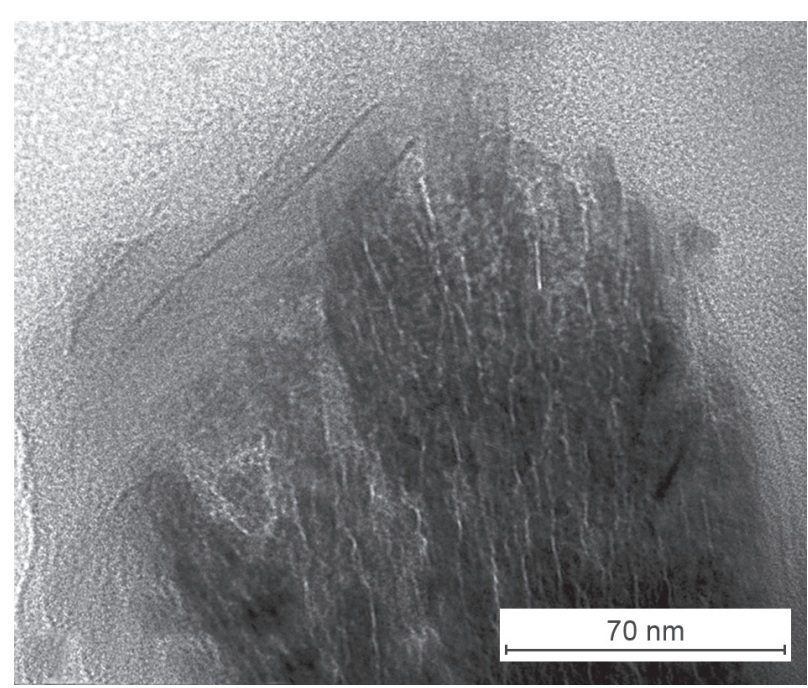

b)

Figure 23. TEM micrographs of blue grains from the surface treatment of the man figurine (a) and the detail of Maya Blue palygorskite/indigo (b).

\section{CONCLUSION}

A unique collection of ceramic figurines from the pre-Columbian classical period of the Maya civilization from the National Museum - Náprstek Museum collection was studied using XRF, XRD, STA, $\mu$-RS, IR and TEM analyses. The results document a great material variety of the ceramic bodies. The multivariate analysis of XRF results showed a distribution of the figurines into four groups. The distribution was confirmed by XRD and STA. It is assumed that the figurine of a fish inv. no. 21503, which was not included into any of the four groups, was not prepared from ceramic raw mixture but from a piece of a calcitic rock. The analyses of decorative layers of selected sculptures proved that the red pigment used to decorate the jaguar figurine inv. no. 21517 contains primarily hematite. The red pigment used to decorate the frog (inv. no. 21454) and the human head (inv. no. 21493) figurines contain an organic cochineal dye; in the case of the head a lower degree of colour intensity is given by the admixture of gypsum. The dark blue dye found on the fragment of the bowl figurine inv. no. 21511 is the famous Maya Blue. A light blue dye, remains of which are on a man figurine inv. no. 21507 , is mainly gypsum and palygorskite with admixes of indigo. The identified palygorskite matches well with palygorskite from the locality near Uxmal where an ancient fabrication of a Maya Blue pigment was documented by archaeologists.

\section{Acknowledgements}

This work was financially supported from specific university research (MSMT No 20-SVV/2017). Financial support from specific university research (MSMT No 20SVV/2018).

\section{REFERENCES}

1. Cabadas-Báez H.V., Jiménez-Álvarez S.P., Leonard D., Lailson-Tinoco B., García-Moll R., Ancona-Aragón I.I., Hernández-Velázquez M.L. (2018): Soils as a source of raw materials for ancient ceramic production in the Maya region of Mexico: Micromorphological insight. Boletín de la Sociedad Geológica Mexicana, 70(1), 21-48. doi: 10.18268/BSGM2018v70n1a2.

2. Sunahara K. S. (2003): Ancient Maya Ceramic Economy in the Belize River Valley Region: Petrographic Analyses. Hamilton, Canada, Dissertation. McMaster University.

3. Chung H., Song Y. (2014) The meaning of volcanic ash characteristics found in the archaeological pottery of Chichen Itza, Yucatan, Mexico. Mediterranean Archaeology and Archaeometry, 14(2), 155-167.

4. Horcajada P., Roldán C. Vidal C., Rodenas I., Carballo J., Murcia S., Juanes D. (2014): Archaeometric study of ceramic figurines from the Maya settlement of La Blanca (Petén, Guatemala). Radiation Physics and Chemistry, 97, 275-283.

5. Halperin C.T., Foias A.E. (2010): Pottery politics: Late Classic Maya palace production at Motul de San José, Petén, Guatemala: Late Classic Maya palace production at Motul de San José, Petén, Guatemala. Journal of Anthropological Archaeology, 29(3), 392-411. doi: 10.1016/j. jaa.2010.06.001. ISSN 0278-4165.

6. Iñañez J., Mardid Fernández M., Molera J., Speakman R., Pradell T. (2013): Potters and pigments: Preliminary technological assessment of pigment recipes of American majolica by synchrotron radiation micro-X-ray diffraction (Sr- $\mu \mathrm{XRD}$ ): Preliminary technological assessment of pigment recipes of American majolica by synchrotron radiation micro-X-ray diffraction (Sr- $\mu \mathrm{XRD})$. Journal of Archaeological Science, 40, 1408-1415. doi: 10.1016/j. jas.2012.09.015.

7. Casanova Municchia A., Micheli M., Ricci M.A., Toledo M., Bellatressia F., Lo Mastro S., Sodo A. (2016): Raman, SEM-EDS and XRPD investigations on pre-Columbian 
Central America "estucado" pottery. Spectrochimica Acta Part A: Molecular and Biomolecular Spectroscopy, 156, 47-53. doi: 10.1016/j.saa.2015.11.023. ISSN 1386-1425.

8. Zhang Y., Fan L., Chen H., Zhang J., Zhang Y., Wang A. (2015): Learning from ancient Maya: Preparation of stable palygorskite/methylene blue@ $\mathrm{SiO}_{2}$ Maya Blue-like pigment: Preparation of stable palygorskite/methylene blue@ $\mathrm{SiO}_{2}$ Maya Blue-like pigment. Microporous and Mesoporous Materials, 211, 124-133. doi: 10.1016/j.micromeso. 2015.03.002. ISSN 1387-1811.

9. Sánchez-Ochoa F., Cocoletzi G.H., Canto G. (2017): Trapping and diffusion of organic dyes inside of palygorskite clay: The ancient Maya Blue pigment: The ancient Maya Blue pigment. Microporous and Mesoporous Materials, 249, 111-117. doi: 10.1016/j.micromeso.2017.04.060. ISSN 1387-1811.

10. Arnold D.E., Bohor B.F., Neff H., Feinman G.M., Williams P.R., Dussubieux L., Bishop R. (2012): The first direct evidence of pre-columbian sources of palygorskite for Maya Blue. Journal of Archaeological Science, 39(7), 2252-2260. doi: 10.1016/j.jas.2012.02.036. ISSN 0305-4403.

11. Tsiantos C., Tsampodimou M., Kacandes G.H., Sánchez del Río M., Gionis V., Chyssikos G.D. (2012): Vibrational investigation of indigo-palygorskite association(s) in synthetic Maya blue. Journal of Materials Science, 47(7), 3415-3428. doi: 10.1007/s10853-011-6189-x. ISSN 15734803.

12. Sánchez del Río M., Doménech A., Doménech-Carbó M.T., Vázquez de Agredos Pascual M.-L., Suárez M., GarcíaRomero E. (2011). The Maya Blue Pigment, in: Galan E., Singer A. (Ed.): Developments in Palygorskite-Sepiolite Research. Elsevier, 3, pp. 453-481. doi: 10.1016/B978-0444-53607-5.00018-9. ISSN 1572-4352.

13. Brunclík J. (1926). Atlas zeměpisný pro školy měštanské. Páté vydání, V. Neubert a synové, Praha. 